\title{
Peningkatan Kinerja Dye-Sensitized Solar Cells menggunakan Metode Ultrasonikasi
}

\author{
Hadi Santoso, ${ }^{*}$ Vicran Zharvan, Rizqa Daniyati, Nur Ichzan AS, Gatut Yudoyono, ${ }^{\dagger}$ dan Endarko \\ Jurusan Fisika, Fakultas Matematika dan Ilmu Pengetahuan Alam, \\ Institut Teknologi Sepuluh Nopember (ITS), Kampus ITS Sukolilo, Surabaya 60111
}

\begin{abstract}
Intisari
Telah dibuat Dye Sensitized Solar Cell (DSSC) yang mampu mengkonversi cahaya menjadi energi listrik dengan memanfaatkan ekstrak kulit manggis sebagai dye sensitizer dan bahan semikonduktor $\mathrm{TiO}_{2}$ sebagai penyusun elektroda kerja. Pembuatan elektroda kerja dibuat dari lapisan $10 \mu \mathrm{m} \mathrm{TiO}_{2}$ terdeposisi pada kaca ITO dengan metode doctor blade yang kemudian dilakukan proses perendaman dalam larutan dye ekstrak kulit manggis dengan menggunakan ultrasonikasi dan tanpa ultrasonikasi dengan waktu perendaman yang singkat yakni 300 sekon. Sementara itu disiapkan elektroda pembanding yakni kaca ITO yang dilapiskan dengan karbon. Antara elektroda kerja dengan elektroda pembanding diberikan elektrolit iodine $\left(\mathrm{I}^{-}\right)$dan triiodide $\left(\mathrm{I}_{3}^{-}\right)$sebagai pasang- an redoks yang menunjang siklus transfer elektron untuk terus berlanjut. Hasilnya menunjukkan bahwa DSSC yang dibuat dengan proses perendaman dye menggunakan ultrasonikasi memberikan efisiensi yang lebih besar.
\end{abstract}

\begin{abstract}
Dye Sensitized Solar Cell (DSSC) which is able to convert light into electrical energy by using mangosteen extract as a dye sensitizer and $\mathrm{TiO}_{2}$ semiconductor material as a photoelectrode has been conducted. $\mathrm{TiO}_{2}$ layer with thickness of $10 \mu \mathrm{m}$ was deposited on top of a ITO glass by doctor blade method and subsequently the $\mathrm{TiO}_{2}$ electrode will be immersion into the dye sensitizer mangosteen extract using with and without ultrasonication method. Immersion time of $\mathrm{TiO}_{2}$ photoelectrode will be investigated at 300 seconds. Meanwhile, prepared ITO glass electrode that is superimposed with carbon. Between the photoelectrode to carbon-electrode is given electrolyte iodine $\left(\mathrm{I}^{-}\right)$and triiodide $\left(\mathrm{I}_{3}^{-}\right)$as a redox couple for support electron transfer cycle continues.
\end{abstract}

KATA KUNCI: dye-sensitized solar cell (DSSC), kulit anggis, ultrasonikasi, efisiensi

\section{PENDAHULUAN}

Sel surya atau fotovoltaik merupakan teknologi yang dapat digunakan untuk mengubah energi matahari menjadi energi listrik. Teknologi ini memiliki emisi $\mathrm{CO}_{2}$ yang rendah dan struktur modular yang fleksibel [1]. Salah satu jenis sel surya yang dikembangkan oleh Grätzel, yang dikenal dengan Dye Sensitized Solar Cells (DSSC) memiliki beberapa keuntungan antara lain proses fabrikasinya mudah dan sederhana sehingga biaya pembuatan dapat lebih murah serta bahan dasarnya mudah diperoleh [2]. Dalam sistem DSSC, energi foton dari cahaya matahari diserap oleh material dye yang menyebabkan terjadinya eksitasi elektron dan menghasilkan pasangan holeelektron. Penelitian terhadap komponen penyusun DSSC telah banyak diteliti untuk memperoleh efisiensi yang baik, salah satunya adalah dye sensitizer (larutan dye).

Peran material donor dan akseptor dalam piranti fotovoltaik konvensioanl, digantikan oleh komponen penghasil muatan dan transfer muatan dalam sistem DSSC. Penghasil muatan

\footnotetext{
*E-MAIL: hadi_santosolscrentist.com

$\dagger$ E-MAIL: gyudoyono@physics.its.ac.id
}

diperankan oleh antarmuka (interface) semikonduktor-dye, sedang transfer muatan diperankan oleh semikonduktor dan elektrolit [3]. Adsorpsi dye pada permukaan semikonduktor berperan penting pada unjuk kerja DSSC, umumnya proses adsorpsi dilakukan dengan cara perendaman lapisan semikonduktor dalam larutan dye selama 24 jam [4-8], atau perendaman semalaman $[9,10]$, tergantung pada ketebalan lapisan semikonduktor dan ukuran partikel. Adapula untuk mempertinggi laju adsorpsi dye dilakukan dengan menambahkan larutan co-adsorbance [11].

Pengurangan waktu proses adsorpsi dye telah dilakukan dengan beberapa cara, seperti mempertinggi konsentrasi larutan [12], menambah temperatur proses [13], memberi larutan asam [14], menggunakan bantuan piranti ultrasonik [15], dan medan listrik [16]. Seo, [15] menggunakan piranti ultrasonik untuk proses adsorpsi dye N719 (dye sintetik) pada permukaan lapisan $\mathrm{TiO}_{2}$.

Pada paper ini dilaporkan hasil perbandingan unjuk kerja sistem DSSC dengan proses adsorpsi larutan dye natural ekstrak kulit manggis pada permukaan lapisan $\mathrm{TiO}_{2}$ menggunakan metode ultrasonikasi. 


\section{METODOLOGI}

\section{Sintesis pasta $\mathrm{TiO}_{2}$}

Nanopartikel $\mathrm{TiO}_{2}$ disintesis menggunakan metode kopresipitasi dengan $\mathrm{TiCl}_{3}$ sebagai sumber Ti. $\mathrm{TiCl}_{3}$ (15\%, Merck) ditambahkan sejumlah aquades serta diaduk (magnetic stirrer) selama 5 jam. pH larutan diatur dengan menambahkan $\mathrm{NH}_{4} \mathrm{OH}$ (28.9\%, Aldrich) hingga $\mathrm{pH} 9$ dan tetap diaduk hingga didapatkan endapan berwarna putih. Endapan dicuci dengan aquades hingga larutan pencuci mempunyai $\mathrm{pH} 7$, kemudian disaring dan dikeringkan. Prekursor $\mathrm{TiO}_{2}$ dikalsinasi pada temperatur $400^{\circ}$ selama 3 jam [17].

Pasta $\mathrm{TiO}_{2}$ dibuat dengan menambahkan 1,4 ml aquades kedalam 0,7 gram serbuk $\mathrm{TiO}_{2}$ dan digerus dengan mortar selama 10 menit. Selanjutnya ditambahkan 0,3 gram PEG$1000,0,7 \mathrm{ml}$ asam asetat, $1 \mathrm{ml}$ acetylacetone dan $0,7 \mathrm{ml}$ triton X-100 [18], sambil diaduk hingga didapatkan pasta yang homogen.

\section{Preparasi elektroda dan pembuatan DSSC}

Pendeposisian pasta $\mathrm{TiO}_{2}$ pada kaca ITO dengan menggunakan metode doctor blade. Penggunaan kaca ITO sebagai substrat fotoanoda (elektroda kerja) dimaksudkan untuk memperbaiki konduktivitas listrik dan transmitansi cahaya yang masuk ke sistem DSSC [19]. Kaca ITO berukuran (2,5 $\times 2,5) \mathrm{cm}^{2}$ diberi pembatas menggunakan plastik pada sisi luar sehingga didapatkan area pendeposisian seluasan $(2 \times$ 2) $\mathrm{cm}^{2}$. Selain digunakan sebagai pembatas daerah deposisi, plastik yang digunakan juga berfungsi untuk kontrol ketebalan lapisan $\mathrm{TiO}_{2}$, pada penelitian ini menggunakan plastik dengan ketebalan $10 \mu \mathrm{m}$, sehingga diharapkan ketebalan lapisan $\mathrm{TiO}_{2}$ yang terbentuk mempunyai ketebalan sekitar $10 \mu \mathrm{m}$. Gong [19] menyebutkan bahwa ketebalan lapisan $\mathrm{TiO}_{2}$ yang optimum untuk digunakan dalam DSSC sekitar 5-30 $\mu \mathrm{m}$. Setelah pasta $\mathrm{TiO}_{2}$ terdeposisi secara merata, langkah berikutnya adalah memberi perlakuan termal untuk menghilangkan molekul-molekul pelarut dengan dipanaskan pada temperatur $450^{\circ} \mathrm{C}$ selama 15 menit.

Adsorpsi larutan dye dalam lapisan $\mathrm{TiO}_{2}$ dilakukan dengan dua metode, yakni perendaman lapisan $\mathrm{TiO}_{2}$ dalam larutan dye dengan dan tanpa ultrasonikasi. Metode pertama (DSSC-1), lapisan $\mathrm{TiO}_{2}$ direndam dalam $10 \mathrm{ml}$ larutan dye dan ditempatkan dalam ultrasonic cleaner (Branson 1510, frekuensi $42 \mathrm{kHz}$ ) selama 300 sekon. Metode kedua (DSSC2), lapisan $\mathrm{TiO}_{2}$ direndam dalam larutan dye tanpa perlakuan ultrasonikasi dengan waktu perendaman yang sama.

Pada penelitian ini digunakan natural dye berupa ekstrak kulit manggis. Larutan dye dibuat dengan mencampurkan 10 gram serbuk ekstrak kulit manggis kedalam $50 \mathrm{ml}$ ethanol kemudian sambil diaduk di atas magnetic stirrer selama 30 menit pada temperatur $60^{\circ} \mathrm{C}$. Larutan dye disaring untuk memisahkan dari endapan yang masih tersisa. Larutan dye diharapkan tidak mengandung serbuk kulit manggis yang berupa endapan karena berpotensi merusak lapisan $\mathrm{TiO}_{2}$ pada proses perendaman secara ultrasonikasi.

Sebelum dilakukan proses penyusunan sandwich DSSC disiapkan bahan penyusun DSSC lainnya. Elektrolit, dalam penelitian ini digunakan elektrolit berupa pasangan iodide dan triiodide $\left(\mathrm{I}^{-} / \mathrm{I}_{3}^{-}\right)$yang bertindak sebagai mediator elektron sehingga dapat menghasilkan proses siklus dalam sel. Elektrolit yang digunakan bersifat gel, karena fase gel ini lebih stabil pada temperatur tinggi dibanding fase cair [20]. Kelemahan lain elektrolit fase cair adalah mudah bereaksi dengan molekul-molekul udara atau air sehingga menurunkan unjuk kerja DSSC, dan juga kesulitan membentuk modul multisel [21]. Selain elektrolit, penyusun lainnya adalah elektroda pembanding. Elektroda pembanding yang digunakan berupa material karbon yang dilapiskan pada kepermukaan kaca ITO. Fungsi karbon sebagai katalis untuk mempercepat reaksi dalam DSSC.

Komponen-komponen DSSC disusun secara sandwich, yang terdiri dari elektoda kerja, elektrolit dan elektroda karbon. Sisi-sisi elektroda kerja dilapisi dengan plastik yang memiliki ketebalan $100 \mu \mathrm{m}, 10 \mu \mathrm{m}$ telah ditempati oleh elekroda kerja, sehingga akan ada ruang $90 \mu \mathrm{m}$ yang dapat diisikan dengan elektrolit gel. Setelah elektrolit diisi, kemudian ditutup dengan elektroda karbon dengan rapat. Agar gel elektrolit tidak mengalir ataupun menguap keluar yang menyebabkan berkurangnya jumlah elektrolit yang digunakan, maka packaging dibuat sedemikian rupa sehingga susunan sandwich terutama elektrolit tetap dalam keadaan dan jumlah yang konstan. Hal tersebut dapat dilakukan dengan memanfaatkan plastik pembatas area dan kontrol ketebalan, dimana plastik tersebut dibiarkan tetap berada pada sisi sel yang telah dibuat, dan dipermukaannya diberikan perekat untuk merekatkan elektroda kerja-elektrolit dengan elektroda karbon. Salah satu titik di konduktif ITO disambungkan kabel sebagai pengalir elektron.

\section{Karakterisasi}

Struktur nanokristalin $\mathrm{TiO}_{2}$ hasil sintesis, dikarakterisasi dengan X-ray diffraction meter (XRD, Xpert MPD). Spektrum absorpsi larutan dye ekstrak kulit manggis diukur menggunakan UV-Vis spectrophotometer (Genesys 10S UV-Vis, Thermo Scientific). Karakterisasi arus dan tegangan (IV) dilakukan menggunakan alat Keithley I-V meter (model 2601A). Berdasarkan data karakteristik I-V devais DSSC, dapat dianalisis parameter sel-surya seperti tegangan opencircuit $\left(\mathrm{V}_{o c}\right)$, arus short circuit $\left(\mathrm{I}_{s c}\right)$, maximum power point (MPP), tegangan dan arus pada $\mathrm{MPP}\left(\mathrm{V}_{M P P}\right.$ dan $\left.\mathrm{I}_{M P P}\right)$, fill factor $(\mathrm{FF})$ dan efisiensi $(\eta)$.

\section{HASIL DAN DISKUSI}

Pola difraksi sinar-X untuk serbuk hasil sintesis ditunjukkan Gambar 1. Pada analisis menggunakan software Match! didapatkan bahwa $\mathrm{TiO}_{2}$ serbuk hasil sintesis mempunyai fasa anatase. Fase anatase ini lebih aktif secara kimiawi ketika digunakan dalam sistem DSSC dibandingkan fase 


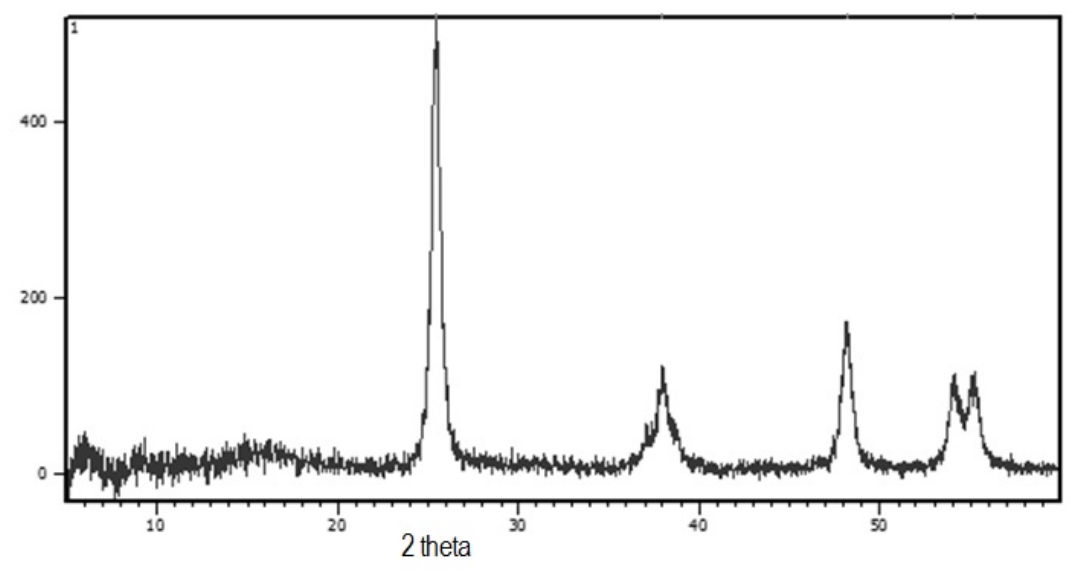

Gambar 1: Pola difraksi XRD serbuk $\mathrm{TiO}_{2}$.

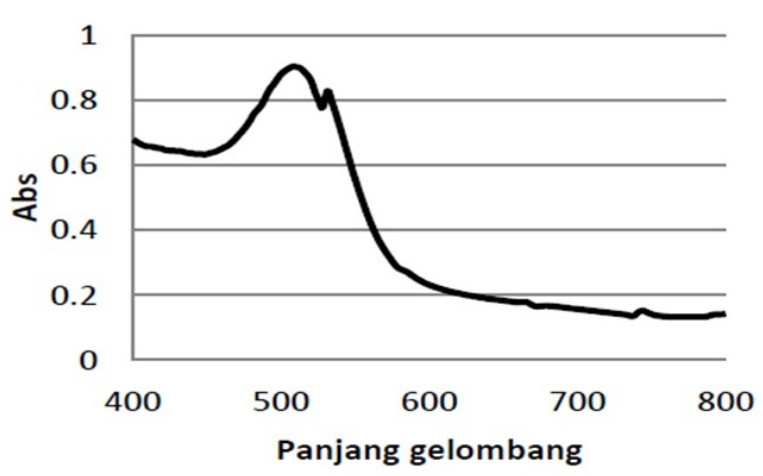

Gambar 2: Absorbansi ekstrak kulit manggis.

rutile, walaupun fase rutile merupakan fase yang paling stabil [19]. Ukuran kristal dari nanomaterial $\mathrm{TiO}_{2}$ hasil sintesis didapatkan sebesar $11,37 \mathrm{~nm}$, yang dihitung menggunakan software Maud.

Spektrum absorbansi dye (ekstrak kulit manggis) diamati dengan spektrofotometer UV-Vis. Larutan dye disiapkan dengan melarutkan ekstrak kulit manggi ke dalam ethanol. Gambar 2 menunjukkan spektrum absorbansi bahan dye sebagai fungsi panjang gelombang berkas cahaya. Analisis spektrum absorbansi menunjukkan bahwa nilai absorpsi tertinggi terletak pada panjang gelombang $528 \mathrm{~nm}$, hal ini menandakan bahwa kemungkinan adanya pigmen antosianin jenis sianidin3-glukosida [22] yang terkandung pada ekstrak kulit. Natural dye bisa didapatkan dari bagian-bagian tumbuhan, seperti daun, bunga, buah, batang, yang terbentuk dalam beberapa jenis pigmen, seperti antosianin, karoten, klorofil [21, 23].

Penggunaan metode ultrasonik memberikan efek sebagai dispersi pada endapan molekul dye, peningkatan difusi molekul dye ke dalam pori $\mathrm{TiO}_{2}$ nanopartikel, dan terjadi pelepasan gas yang terperangkap pada lapisan $\mathrm{TiO}_{2}$ berpori secara cepat. Penggunaan waktu yang singkat, bertujuan untuk mencegah agar proses ultrasonik tidak merusak lapisan $\mathrm{TiO}_{2}$, karena pada dasarnya ultrasonik mempengaruhi larutan dye untuk menghasilkan gaya dorong yang bergerak tak be-

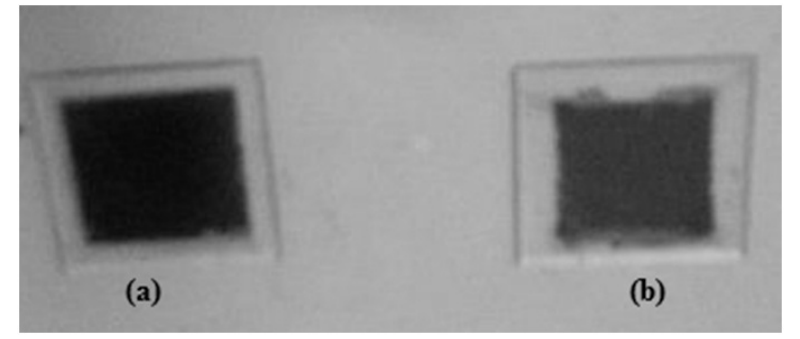

Gambar 3: Hasil perendaman (a) menggunakan ultrasonikasi, tampak lebih gelap dan (b) tanpa ultrasonikasi, tampak lebih cerah.

TABEL I: Parameter DSSC.

\begin{tabular}{ccccccc}
\hline \hline Sampel & $\begin{array}{c}\mathrm{I}_{s c} \\
(\mathrm{~mA})\end{array}$ & $\begin{array}{c}\mathrm{V}_{o c} \\
(\mathrm{mV})\end{array}$ & $\begin{array}{c}\mathrm{V}_{M P P} \\
(\mathrm{volt})\end{array}$ & $\begin{array}{c}\mathrm{I}_{M P P} \\
(\mathrm{~mA})\end{array}$ & $\begin{array}{c}\mathrm{FF} \\
(\%)\end{array}$ & $\begin{array}{c}\eta \\
(\%)\end{array}$ \\
\hline & & & & & & \\
DSSC-1 & 0,046 & 0,31 & 0,16 & 0,03 & 34 & $0,42 \%$ \\
DSSC-2 & 0,06 & 0,22 & 0,085 & 0,036 & 22 & $0,17 \%$
\end{tabular}

raturan sehingga bila dioperasikan dalam waktu yang cukup lama akan berpotensi untuk mengikis lapisan $\mathrm{TiO}_{2}$. Gambar 3 memberikan informasi kualitatif bahwa kandungan yang dimiliki Gambar 3(a) yang menggunakan ultrasonikasi memiliki warna yang lebih gelap, ini menunjukan bahwa kandungan dye yang teradsorpsi cukup banyak. Sedangkan Gambar 3 (b) yang menggunakan metode tanpa ultrasonikasi memiliki warna yang lebih cerah, menunjukan bahwa kandungan dye pada elektroda kerja lebih sedikit.

Karakterisasi listrik sistem DSSC dilakukan menggunakan I-V meter dengan disinari lampu halogen dengan daya 1000 Watt $/ \mathrm{m}^{2}$ (Solar Power meter TES-1333R). Gambar 4 menunjukkan grafik karakteristik photocurrent-voltage sistem DSSC-1 dan DSSC-2.

Hasil analisis data pengukuran photocurrent-voltage sistem DSSC-1 dan DSSC-2 ditunjukkan Tabel I. Berdasarkan analisis data diperoleh bahwa DSSC-1 lebih baik dibandingkan DSSC-2, hal ini disebabkan beberapa hal, pertama 


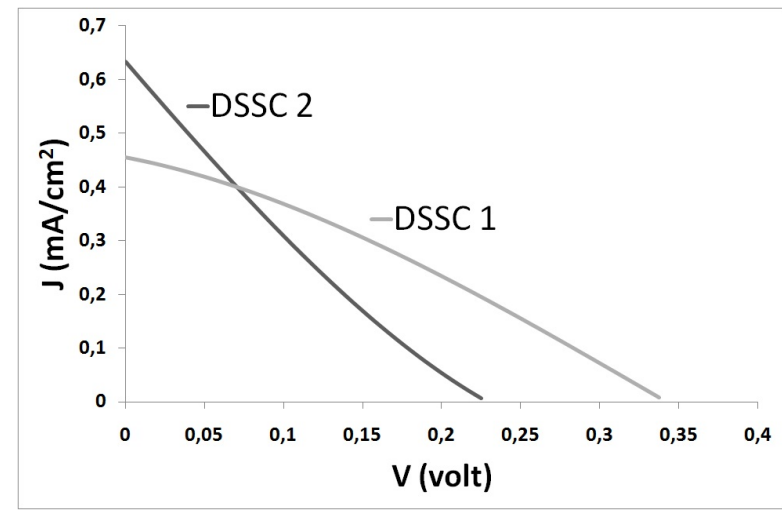

Gambar 4: Karakteristik photocurrent-voltage sistem DSSC

pengaruh perendaman elektroda kerja dengan ultrasonikasi dalam waktu yang singkat memberikan pengaruh yang cukup mengadsorpsi dye, ini terlihat dari Gambar 3(a) yang menunjukan bahwa elektroda yang diproses dengan cara ultrasonikasi berhasil mengikat dye lebih banyak dibandingkan elektroda tanpa proses ultrasonikasi (Gambar 3(b)) yang bi- asanya membutuhkan waktu yang relatif lebih lama. Penggunaan metode ultrasonikasi mampu meningkatkan unjuk kerja sistem DSSC, yang ditunjukkan oleh nilai efisiensi yang lebih besar dibanding tanpa ultrasonikasi. Penggunaan dye natural berupa ekstrak kulit manggis yang memberikan efisiensi 0,42\% ini masih lebih rendah dibandingkan hasil penelitian peneliti lainnya $[20,21,23]$, walaupun demikian hasil ini masih lebih tinggi dibandingkan hasil penelitian sebelumnya [24].

\section{SIMPULAN}

Pada proses perendaman elektroda kerja kedalam larutan dye dalam waktu yang singkat dapat digunakan proses ultrasonikasi pada alat ultrasonic cleaner. Pada proses perendaman elektroda kerja kedalam larutan dye dalam waktu yang singkat metode ultrasonikasi lebih baik dibandingkan tanpa ultrasonikasi. DSSC yang dibuat dengan proses perendaman elektroda dengan dan tanpa ultrasonikasi memiliki efesiensi masing-masing $0,42 \% ; 0,17 \%$.
[1] M.K. Moorhty, D.V.A. Kumar, and J.N. Reddy, Control of Grid Connected PV Cell Distributed Generation Systems, IEEE Region 10 Conferences, 18 - 21 November 2008, Hyderabad, India (2008).

[2] B. O'regan, and M. Grätzel, Nature, 353(6346), 737-780 (1991).

[3] M.K. Nazeeruddin, E. Baranoff, M. Grätzel, Sol. Energy, 85, 1172-1178 (2011).

[4] Y. Lee, M. Kang, Mater. Chem. Phys., 122, 284-289 (2010).

[5] M. Li, et al., Appl. Energy, 88, 825-830 (2011).

[6] H. Choi, et al., Curr. Appl. Phys., 12, 737-741 (2012).

[7] B. Hu, et al., J. Power Sources, 267, 445-451 (2014).

[8] M.-G. Choi, Y.-M. Sung, Opt. Mater., 36, 1430-1435 (2014).

[9] A. Subramanian, H.-W. Wang, J. Photochem. Photobiol. Chem., 279, 32-37 (2014).

[10] N.-Q. Fu, et al., Electrochem. Commun., 34, 254-257 (2013).

[11] R. Hou, et al., Electrochimica Acta, 154, 190-196 (2015).

[12] M.K. Nazeeruddin, et al., Chem. Commun., 12, 1456-1457 (2003).

[13] F. Hirose, et al., J. Electrochem. Soc., 157, B1578-B1581 (2010).

[14] B. Kim, et al., Appl. Mater. Interface., (2013) A-G. doi:10. 1021/ am401034r.

[15] Y. Seo, J.H. Kim, J. Ind. Eng. Chem., 19, 488-492 (2013).
[16] H. Seo, et al., Electrochimica Acta, 55, 4120-4123 (2010).

[17] V. Zharvan, R. Daniyati, N. Ichsan, G. Yudoyono, Darminto, Study on Fabrication of $\mathrm{TiO}_{2}$ Thin Films by Spin-coating and their Optical Properties, The $4^{\text {th }}$ International Conference on Theoretical and Applied Physics (ICTAP-2014), Denpasar-Bali, 2014.

[18] L.J. Kook, et al., J. Ind. Eng. Chem., 15, 724-729 (2009).

[19] J. Gong, J. Liang, K. Sumanthy, Renew. Sustain. Energy Rev., 16, 5848-5860 (2012).

[20] H. Hug, M. Bader, P. Mair, T. Glatzel, Appl. Energy, 115, 216255 (2014).

[21] M.R. Narayan, Renew. Sustain. Energy Rev., 16, 208-215 (2012).

[22] W. Supiyanti, D.W. Endang, L. Kusmita, Uji Aktivitas Antioksidan dan Penentuan Kandungan Antosianin Total Kulit Buah Manggis (Granicia mangostana L), Majalah Obat Tradisional, 15, 62 (2010).

[23] N.A. Ludin, et al., Renew. Sustain. Energy Rev., 31, 386-396 (2014).

[24] N. Puspitasari, Characterization Dye Sensitized Solar Cells based on $\mathrm{TiO}_{2}$ using a Variation of Natural dyes and Thickness of $\mathrm{TiO}_{2}$ layer, Thesis Fisika, FMIPA-ITS, Surabaya, 2013. 